\title{
Magmatic Plumbing Systems of the Koryakskii-Avacha Volcanic Cluster as Inferred from Observations of Local Seismicity and from the Regime of Adjacent Thermal Springs
}

\author{
A. V. Kiryukhin ${ }^{a, *}$, S. A. Fedotov ${ }^{a}$, P. A. Kiryukhin ${ }^{b}$, and E. V. Chernykh ${ }^{a}$ \\ ${ }^{a}$ Institute of Volcanology, Far East Branch, Russian Academy of Sciences, \\ bul'var Piipa 9, Petropavlovsk-Kamchatskii, 683006 Russia \\ ${ }^{b}$ OOO Eksidzhen Servisis, Pulkovskoe shosse, 40-1, St. Petersburg, 196158 Russia \\ *e-mail: AVKiryukhin2@mail.ru \\ Received November 2, 2016
}

\begin{abstract}
An analysis of local seismicity within the Avacha-Koryakskii Volcanic Cluster during the 20002016 period revealed a sequence of plane-oriented earthquake clusters that we interpret as a process of dike and sill emplacement. The highest magmatic activity occurred in timing with the 2008-2009 steam-gas eruption of Koryakskii Volcano, with magma injection moving afterwards into the cone of Avacha Volcano (2010-2016). The geometry of the magma bodies reflects the NF geomechanical conditions (tension and normal faults, $S_{\mathrm{v}}>S_{H_{\max }}>S_{h_{\min }}$ ) at the basement of Koryakskii Volcano dominated by vertical stresses $S_{\mathrm{v}}$, with the maximum horizontal stress $S_{H_{\max }}$ pointing north. A CFRAC simulation of magma injection into a fissure under conditions that are typical of those in the basement of Koryakskii Volcano (the angle of dip is $60^{\circ}$, the size is $2 \times 2 \mathrm{~km}^{2}$, and the depth is $-4 \mathrm{~km}$ abs.) showed that when the magma discharge is maintained at the level of $20000 \mathrm{~kg} / \mathrm{s}$ during 24 hours the fissure separation increases to reach $0.3 \mathrm{~m}$ and the magma injection is accompanied by shear movements that occur at a rate as high as $2 \times 10^{-3} \mathrm{~m} / \mathrm{s}$, thus corresponding to the conditions of local seismic events with Mw below 4.5. We are thus able to conclude that the use of planeoriented clusters of earthquakes for identification of magma emplacement events is a physically sound procedure. The August 2, 2011 seismicity increase in the area of the Izotovskii hot spring ( $7 \mathrm{~km}$ from the summit of Koryakskii Volcano), which is interpreted as the emplacement of a dike, has been confirmed by an increase in the spring temperature by $10-12^{\circ} \mathrm{C}$ during the period from October 2011 to July 2012.
\end{abstract}

DOI: $10.1134 / \mathrm{S} 0742046317050049$

\section{INTRODUCTION}

The description of magmatic plumbing systems beneath volcanoes, that is, their structure, evolution, and how they function, is a major problem in volcanology; a solution of that problem would lead to important applications for the prediction of volcanic eruptions, the assessment of geothermal resources, the conditions for the formation of geothermal, mineralizing, and some types of hydrocarbon fields, as well as in connection with technologies employed for developing man-made circulation systems (by hydraulic fracturing) for extracting or burying fluids of diverse compositions (EGS ("hot dry rocks"), shale gas, tight oil reserves, etc.). One of the fundamental factors that cause transport of fluids in the upper brittle crustal shell is hydraulic fracture and activation of critically compressed plane-oriented fissures and faults during their evolution (Zoback, 2010). The conditions that favor hydraulic fracturing (magmatic fracturing) in application to magma reservoirs can consist in increased pressure of magma in the chamber or the decreasing minimum stress of the host rocks (Gudmundsson, 2015). The seismicity that accompanies the generation of shear fissures due to hydraulic fracture (triggered seismicity) is fairly well described in (Zoback, 2010; Nicolas et al., 2011; McClure and Horne, 2013) and can be used for identification of the geometry of productive reservoirs of geological fluids.

Studies of volcanic eruptions in Kamchatka show spectacular events where dikes are emplaced; these manifest themselves as linearly oriented centers of local eruptions or as tension fissures at the ground surface. The analysis of data from observations of the 1975-1976 Great Tolbachik Fissure Eruption led to a series of publications (Fedotov, 1976, 1982) where hydrodynamic and thermal calculations were used to estimate the minimum and maximum rates of magma motion in dikes under specified input and output magma temperatures, host rock temperature, fissure opening, and the excess pressure in the magma chamber. Observations of the eruption in the Akademii Nauk Caldera and of one on Karymskii Volcano revealed tension fissures related to the emplacement of 
a dike whose inferred length was $4.7 \mathrm{~km}$ and thickness $0.7 \mathrm{~m}$ in dense crustal layers (Fedotov, 1997).

The understanding of the important role played by plane-oriented magma bodies (dikes and sills) in effecting the transport of magma from crustal to peripheral magma chambers and further to the ground surface has become much deeper in recent years due to the use of seismic data, high-precision geodetic measurements, and satellite-based radar surveys and GPS/GLONASS networks of stations (Lundgren et al., 2015).

As an example, Sigmundsson et al. (2015) described the generation of a giant segmented dike and the 2014-2015 eruption of Barrparbunga Volcano in Iceland. The volcano (the caldera is $8 \times 11 \mathrm{~km}$ in size, with 23 eruptions occurring during the past 1100 years) is situated in the middle of the Iceland Rift Zone (the extension rate is $19 \mathrm{~mm} / \mathrm{yr}$ ). Its magma chamber is thought to lie at depths of $10-15 \mathrm{~km}$. The volume of erupted olivine tholeiitic lava is estimated to be $1.4 \mathrm{~km}^{3}$ (this is the largest effusion of lava in Iceland since 1783). To be precise, seismic data helped find the shape of a $50-\mathrm{km}$ dike that supplied magma for the eruption; the dike consists of 11 plane-oriented segments (clusters had 57 to 1181 earthquakes in them, with some events being larger than magnitude 5). The dike was emplaced during 22 days. It is of interest to note that the first segment of the dike is oriented along the normal to the caldera boundary, while all the subsequent segments are along the trend of the rift zone. The eruption began at the farthest end of the dike and lasted for 6 months. Apart from seismicity, satellitebased radar surveys (Cosmo-SkyMed, TerraSAR-X) and GPS observations revealed that the dike walls were distended by $320 \mathrm{~cm}$, the dike volume is estimated as $0.6 \mathrm{~km}^{3}$, and the average discharge of magma was $260 \mathrm{~m}^{3} / \mathrm{s}$. The caldera is estimated to have subsided by $60 \mathrm{~m}$ during these 6 months, with the volume of the subsidence being $1.9 \mathrm{~km}^{3}$; the magma chamber that supplied magma shrank by $0.3 \mathrm{~km}^{3}$.

Dumont et al. (2017) quote data on the activation of the Afar Rift System, Ethiopia in 2005-2010 accompanied by dike intrusions (the zone of dike emplacement extends for $60 \mathrm{~km}$ along the rift, and is approximately $5 \mathrm{~km}$ wide), which can be inferred from seismic and geodetic (InSAR) data. The source of magma is thought to have been a mid-segment magma chamber (MSMC) that includes a shallow peripheral magma chamber $(\sim 4 \mathrm{~km})$ and a deeper lying magma chamber (at a depth greater than $15 \mathrm{~km}$ ), with dike intrusions ( $\sim 15 \mathrm{~km}$ long) occurring in different directions from the original magma chamber along the rift zone axis.

The Koryakskii-Avacha volcanogenic basin is a standard object for monitoring and analysis of the processes that accompany magma injection from magma chambers beneath volcanoes during active periods; the most significant of such periods occurring in
2008-2009 (Gordeev et al., 2009; Seliverstov, 2009; Senyukov and Nuzhdina, 2010; Lemzikov and Lemzikov, 2015). The seismicity in the AvachaKoryakskii Volcanic Cluster area is recorded by six stations (Senyukov and Nuzhdina, 2010); the variation in the thermal power output of fumaroles in volcanic craters is assessed using thermal imaging surveys (Gordeev and Droznin, 2010); continuous observations of the hydrogeological regime of ground water at the Pinachevo Springs and at well E-1 in the southwestern part of the basin are being conducted (Kopylova and Boldina, 2012), while the northern slope of Koryakskii Volcano is being monitored to observe the temperature and hydrochemical gas regime of thermal springs that are discharged there (Kiryukhin et al., 2015).

The structure of magmatic conduits of Avacha and Koryakskii volcanoes is intimately related to the conditions for the formation of geothermal resources in the volcanogenic basin. There are geological and geophysical data that allow an approximate estimate for the geometry of the magma chamber beneath Avacha Volcano as an ellipsoid (Fedotov, 2006; Fedotov et al., 2007): the top of the magma chamber is estimated to lie between zero sea level and $2 \mathrm{~km}$ below sea level, while the horizontal and vertical semi-axes of the ellipsoid are at least 2.3 and $1.53 \mathrm{~km}$ when based on the $900^{\circ} \mathrm{C}$ isotherm and at least 4.5 and $3 \mathrm{~km}$ when determined from the $700^{\circ} \mathrm{C}$ isotherm, respectively. Longterm exploitation of the underground circulation system for 100 years will yield approximately $250 \mathrm{MW}$ of electrical energy from the block of hot rock whose volume is approximately $50 \mathrm{~km}^{3}$ (Fedotov, 2006; Fedotov et al., 2007).

The report for contract no. 25/12/14 as of December 25, 2014 A Study of Geothermal Resources in the Avacha Volcanic Cluster, Kamchatka Peninsula, Kamchatskii Krai https://cloud.mail.ru/public/Hu5r/MjhiTXRfD (headed by Dr. Sci. (Eng.) R.I. Pashkevich, NIGTTs DVO RAN) reviewed the published data (Shteinberg et al., 1963; Polyak, 1964; Fedotov, 2006; Fedotov et al., 2007) with the following results: (1) The authors concluded that the edifice of Avacha Volcano produces geophysical anomalies of various origins (gravity and magnetic anomalies, as well as anomalies in seismic velocities). The anomalous body that is responsible for these anomalies has the shape of an ellipsoid (which is interpreted as being a magma chamber with a temperature of $700^{\circ} \mathrm{C}$ ) whose top is no deeper than $-2 \mathrm{~km}$ abs. and whose horizontal and vertical semi-axes are $4.5 \mathrm{~km}$ and $3 \mathrm{~km}$ long, respectively.

(2) The temperature as measured in exploration wells at a distance of $20 \mathrm{~km}$ from the volcano does not exceed $24-33^{\circ} \mathrm{C}$ down to depths of $1.1-1.5 \mathrm{~km}$.

(3) The authors of the report developed a 3D thermal hydrodynamic model for Avacha Volcano and the adjacent ground water basin (at a distance of $13 \mathrm{~km}$ 
from the volcano); the modeling results led the authors to the conclusion that a zone of overheated water of temperature over $150^{\circ} \mathrm{C}$ is being formed at depths above $1.5 \mathrm{~km}$ and at a distance less than $7 \mathrm{~km}$ from the active crater (p. 75).

(4) The modeling results were used to assess the specifications of a pilot geothermal station with a power output as large as $120 \mathrm{MW}$ (p. 75). However, the above results evidently require additional research to refine the geometry of the magma plumbing systems.

In connection with resumed exploration for sources of geothermal heat and electrical supply in the Koryakskii-Avacha Volcanic Cluster (R.I. Pashkevich, personal communication, 2015), it appears that more accurate determinations of the existing distributions of active magma bodies and of the mechanisms of magma transport in volcanic conduits present an urgent problem as well.

A.V. Kiryukhin et al. $(2015,2016)$ proposed a method for identifying and estimating the geometry of magmatic plumbing systems of volcanoes (dikes and sills) based on local seismicity data. This method was described in detail for the 2012-2013 eruption of Tolbachik Volcano with more data on the 2008-2010 activation of the Koryakskii-Avacha Volcanic Cluster. The present paper furnishes a more detailed and complete (supplemented with observations in 2014-2016) description of the magmatic plumbing system beneath the Koryakskii-Avacha Volcanic Cluster, estimates the geomechanical conditions at the basement of this cluster, simulates magma emplacement into a fissure zone that is typical of the current conditions, and quotes factual data on the thermal action of a dike on the discharge of a nearby thermal spring.

\section{A GEOMECHANICAL ANALYSIS OF LOCAL SEISMICITY OBSERVED IN THE AVACHA-KORYAKSKII VOLCANIC CLUSTER AREA IN 2000-2013}

\subsection{The History of Magma Injection, the Geomechanical State of the Koryakskii-Avacha Volcanic Cluster}

The raw data, as well as the method and criteria for identification of plane-oriented earthquake clusters as observed during the 2008-2010 active period of Koryakskii and Avacha volcanoes were described by Kiryukhin et al. (2016). For the present study the catalog of seismic data (January 200 to January 2013) was used along with published data (Zemletryaseniya ..., $2015,2016)$ and with data from the Preliminary Catalog compiled at the Kamchatka Branch, Geophysical Survey, Russian Academy of Sciences (KB GS RAS) for 2015-2016. The total number of seismic events we consider was increased to reach $5160(\max \mathrm{Ks}=9.8)$. The absolute uncertainty of hypocenter and epicenter location for microearthquakes in the Koryakskii-Avacha Volcanic Cluster area is estimated as $1 \mathrm{~km}$ (Zemle- tryaseniya ..., 2015, 2016). The detection and estimation of characteristics for plane-oriented clusters was carried out using the FracDigger program (state-registered as no. 2016616880), with the Surfer v.13 program being used for visualization.

It was shown, in particular, that the summit steam-gas eruption of Koryakskii Volcano in 20082009 was accompanied by 153 plane-oriented clusters of earthquakes that were interpreted as zones where dikes and sills were emplaced during magma injection. The first phase in the pre-eruption period began as magma saturating the crustal chamber (the top is at $-3 \mathrm{~km}$ abs. and the diameter is $2.5 \mathrm{~km}$ ) at the southwestern base of Koryakskii Volcano (July 2008 to January 2009). Further magma injection in a nearly north-south zone $(7.5 \times 2.5 \mathrm{~km}$, the main range of depth was from -2 to $-5 \mathrm{~km}$ abs.) in the northern sector of Koryakskii Volcano occurred in parallel with the most intensive period of the summit steam-gas eruption (February 2009 to March 2010). The injection was occurring at a pressure of $53 \mathrm{MPa}$ (at a depth of $6 \mathrm{~km}$ ) and was accompanied by dike emplacement $\left(84^{\circ}-87^{\circ}\right)$ that was simultaneous with the generation of inclined dikes (dip angles were $34^{\circ}-82^{\circ}$ ). The highest density of magma fractures was observed in a volume of $45 \mathrm{~km}^{3}$ that was being saturated with magma melt to varying degrees. The presence of more gently dipping dikes with dip angles of $4-30^{\circ}$ that do not plot in the zone of shear failure in the Mohr diagram indicates that local molten magma chambers and permeable stratiform reservoirs might exist in this volume. When the magmatic plumbing system beneath Koryakskii Volcano was saturated with magma, it began to be injected into the cone of Avacha Volcano (2010); the process persists until the present (October 2016). Thirty dikes were emplaced in the cone of Avacha Volcano during this period. Table 1 contains the characteristics of the dikes and sills that have been identified from plane-oriented earthquake clusters with a number of events of at least 10 . We also note magmatic activity on the northern slope of Koryakskii Volcano in the area of the Izotovskii Spring and Koryakskii Narzany (four dikes for the period between October 2009 and February 2016, Table 2).

Figures 1-4 show projections of magma emplacements (dikes and sills) and the distribution of earthquakes in the edifices and basement of the AvachaKoryakskii Volcanic Cluster at horizontal cross sections through $-3000 \mathrm{~m}$ abs., $-1000 \mathrm{~m}$ abs., and $+1500 \mathrm{~m}$ abs., in vertical cross sections $\mathrm{AB}$ and $\mathrm{CD}$ (striking NNE) and EF (striking NW). A careful analysis of the orientations of the dikes and sills (using stereograms and histograms) shows the following: (1) the dikes beneath Koryakskii Volcano were mostly emplaced in the depth range between $-5000 \mathrm{~m}$ abs. and $0 \mathrm{~m}$ abs.; they mostly strike north-south (75\% of the dikes have azimuths between $320^{\circ}$ and $40^{\circ}$ ) and have dip angles over $50^{\circ}$ ( $70 \%$ of the dikes) and (2) the dikes beneath Avacha Volcano were mostly recorded in the depth range 


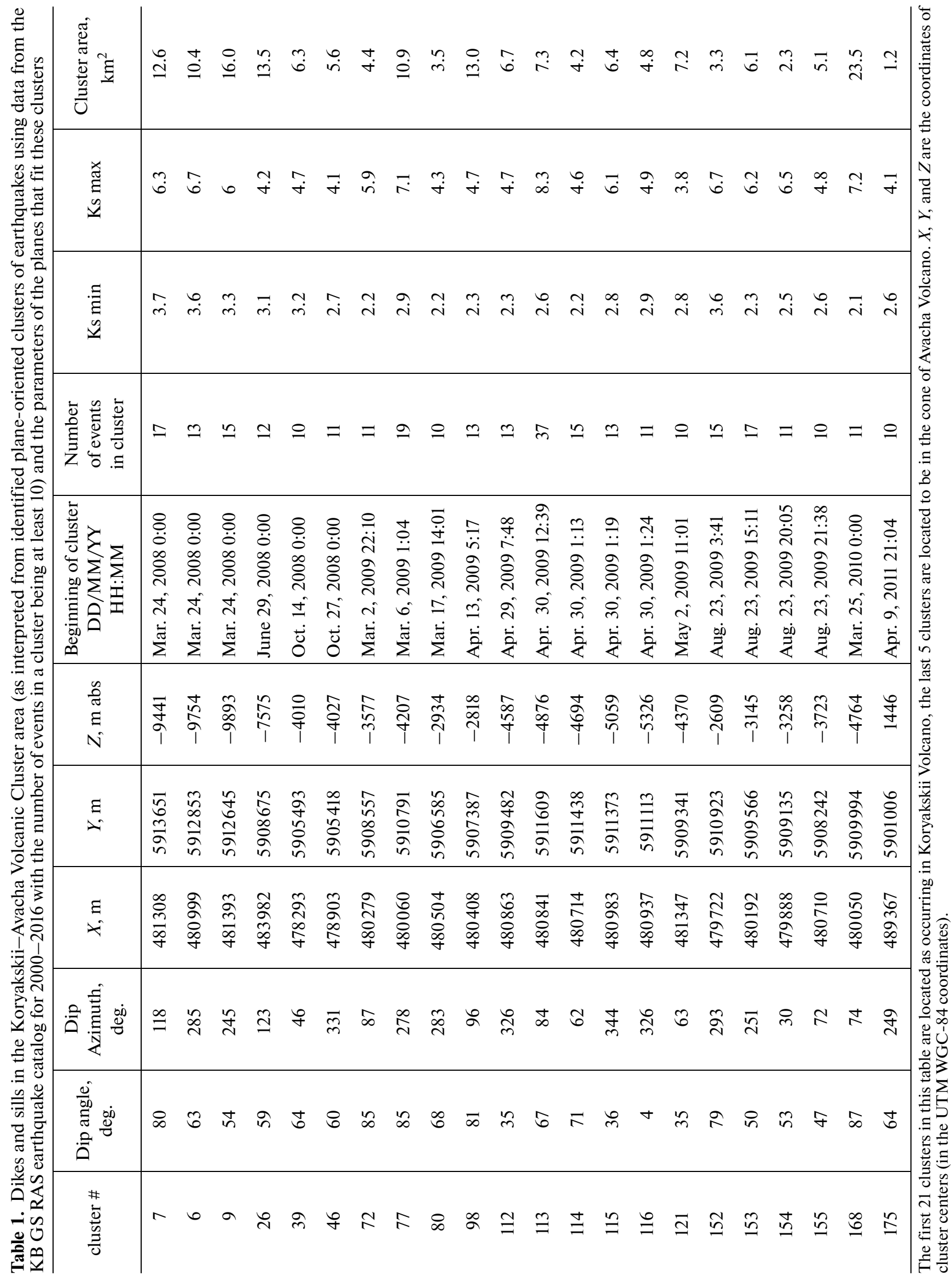


Table 2. Dikes in the area of the Izotovskii Spring and Koryakskii Narzany (as interpreted from identified plane-oriented clusters of earthquakes from the KB GS RAS for 2000-2016) and the parameters of the fitted planes

\begin{tabular}{c|c|c|c|c|c|c|c|c|c|c}
\hline $\begin{array}{c}\text { Cluster } \\
\#\end{array}$ & $\begin{array}{c}\text { Dip } \\
\text { angle, } \\
\text { deg. }\end{array}$ & $\begin{array}{c}\text { Dip } \\
\text { azimuth, } \\
\text { deg. }\end{array}$ & $X, \mathrm{~m}$ & $Y, \mathrm{~m}$ & $Z, \mathrm{~m}$ abs & $\begin{array}{c}\text { Beginning } \\
\text { of cluster } \\
\text { DD/MM/YY } \\
\text { HH:MM }\end{array}$ & $\begin{array}{c}\text { Number } \\
\text { of events } \\
\text { in cluster }\end{array}$ & Ks min & Ks max & $\begin{array}{c}\text { Cluster } \\
\text { area, } \mathrm{km}^{2}\end{array}$ \\
\hline 163 & 76 & 290 & 481738 & 5913884 & -4343 & Oct. 8, 2009 21:04 & 8 & 2.9 & 3.8 & 12.8 \\
165 & 73 & 298 & 481745 & 5912929 & -4682 & Nov. 22, 2009 7:18 & 6 & 3.1 & 3.6 & 2.5 \\
194 & 39 & 115 & 479151 & 5914685 & -2413 & Aug. 2, 2011 14:13 & 7 & 2.5 & 7.4 & 1.5 \\
204 & 70 & 64 & 480792 & 5914003 & -2187 & Feb. 28, 2016 1:42 & 7 & 2.3 & 6.4 & 1.7 \\
\hline
\end{tabular}

$X, Y$, and $Z$ are the coordinates of cluster centers (in the UTM WGC-84 coordinates).

between $+1000 \mathrm{~m}$ abs. and $+2000 \mathrm{~m}$ abs., their strikes are uniformly distributed over all possible directions, but there is a local maximum of dikes striking nearly north-south ( $25 \%$ of the dikes with azimuths between $350^{\circ}$ and $10^{\circ}$ ); steeply dipping dikes are not obviously dominant $\left(61 \%\right.$ have dip angles over $\left.45^{\circ}\right)$.

The information set forth above furnishes some data to estimate the geomechanical condition beneath the volcanoes of interest as follows (here and below, we shall denote the principal stresses following (Zoback, 2010)): (1) tension is recorded beneath Koryakskii Volcano producing normal faulting, the vertical stress $S_{\mathrm{v}}$ is the maximum stress, the horizontal principal stresses are coincident with the north-south $\left(S_{H_{\max }}\right)$ and the east-west $\left(S_{h_{\min }}\right)$ direction, $S_{\mathrm{v}}>S_{H_{\max }}>$ $S_{h_{\min }}$ and (2) the cone of Avacha Volcano is found to be under conditions more similar to radial tension $S_{\mathrm{v}}>$ $S_{H_{\max }} \approx S_{h_{\min }}$. The Mohr diagrams (Figs. 5 and 6) plotted for the geomechanical conditions indicated above enable us to estimate magma pressure at the time of dike emplacement: $7 \mathrm{MPa}$ at a depth of $1000 \mathrm{~m}(\approx 1500 \mathrm{~m}$ abs.) for Avacha Volcano (see Fig. 5) and $45 \mathrm{MPa}$ for Koryakskii at a depth of $6000 \mathrm{~m}(\approx-3000 \mathrm{~m}$ abs. $)$ (see Fig. 6).

Based on the above, the geomechanical state is NF (normal faulting or tension) for Koryakskii Volcano in the depth range between $-5000 \mathrm{~m}$ abs. and $1000 \mathrm{~m}$ abs. and for Avacha Volcano in the depth range between $0 \mathrm{~m}$ abs. and $2000 \mathrm{~m}$ abs.; this state can be written as a stress tensor in the geographic coordinates $X, Y, Z$ ( $X$ denotes the eastward direction, $Y$ indicates the northward direction, and $Z$ denotes the upward direction) as follows:

$$
S_{\mathrm{g}}=\left(\begin{array}{ccc}
S_{x x}-P_{\mathrm{f}} & 0 & 0 \\
0 & S_{y y}-P_{\mathrm{f}} & 0 \\
0 & 0 & S_{z z}-P_{\mathrm{f}}
\end{array}\right),
$$

where $S_{x x}=S_{h_{\min }}, S_{y y}=S_{H_{\max }}, S_{z z}=S_{\mathrm{v}}, P_{\mathrm{f}}$ is the pressure of the fluid (magma).

The stress components beneath Koryakskii Volcano at depth $z_{0}=6000 \mathrm{~m}(\approx-3000 \mathrm{~m}$ abs. $)$ are esti- mated as follows: $S_{\mathrm{v}}=\int_{0}^{Z_{0}} \rho g d z=(2200 \times 9.81 \times 4000+$ $2700 \times 9.81 \times 2000)=139 \mathrm{MPa}($ where $\rho$ is rock density, assumed to be $2200 \mathrm{~kg} / \mathrm{m}^{3}$ for the upper section of the volcanogenic basin and $2700 \mathrm{~kg} / \mathrm{m}^{3}$ for the preCretaceous basement); $S_{h_{\min }}=S_{\mathrm{v}} / 3.1=44.8 \mathrm{MPa}$; $S_{H_{\max }}$ was assumed to be equal to $\left(S_{\mathrm{v}}+S_{h_{\min }}\right) / 2=92$ MPa. The initial tensor of effective stress for Koryakskii Volcano (1) at a magma pressure of $45 \mathrm{MPa}$ in the geographic coordinates ( $X$, eastward; $Y$, northward; and $Z$, upward) can then be written as

$$
S_{\mathrm{g}}=\left(\begin{array}{ccc}
0 & 0 & 0 \\
0 & 47 & 0 \\
0 & 0 & 94
\end{array}\right)
$$

The stress components beneath Avacha Volcano at depth $z_{0}=1000 \mathrm{~m}(\approx 1500 \mathrm{~m}$ abs. $)$ are estimated as follows: $S_{\mathrm{v}}=\int_{0}^{z_{0}} \rho g d z=2200 \times 9.81 \times 1000=21.6 \mathrm{MPa}$ (where $\rho$ is the rock density, assumed to be $2200 \mathrm{~kg} / \mathrm{m}^{3}$ for the upper section of the volcanogenic basin); $S_{h_{\min }}=$ $S_{H_{\max }}=S_{\mathrm{v}} / 3.1=7 \mathrm{MPa}$. The initial tensor of the effective stress for Avacha Volcano is then found from (1) assuming the fluid (magma) pressure to be $7 \mathrm{MPa}$ in the geographic coordinates $(X$ denotes the eastward direction; $Y$, the northward; and $Z$, the upward) as follows:

$$
S_{\mathrm{g}}=\left(\begin{array}{ccc}
0 & 0 & 0 \\
0 & 0 & 0 \\
0 & 0 & 14.6
\end{array}\right) .
$$

As we transform from the geographic $X, Y, Z$ coordinates to those of a fissure $X 2, Y 2, Z 2$ (strike $\alpha$, dip angle $\beta$, the $X 2$ axis in the plane of the fissure along the strike, the $Y 2$ axis in the fissure plane along the strike, the $Z 2$ axis is perpendicular to the fissure plane and points upward), the transformation matrix $A$ is written as follows: 


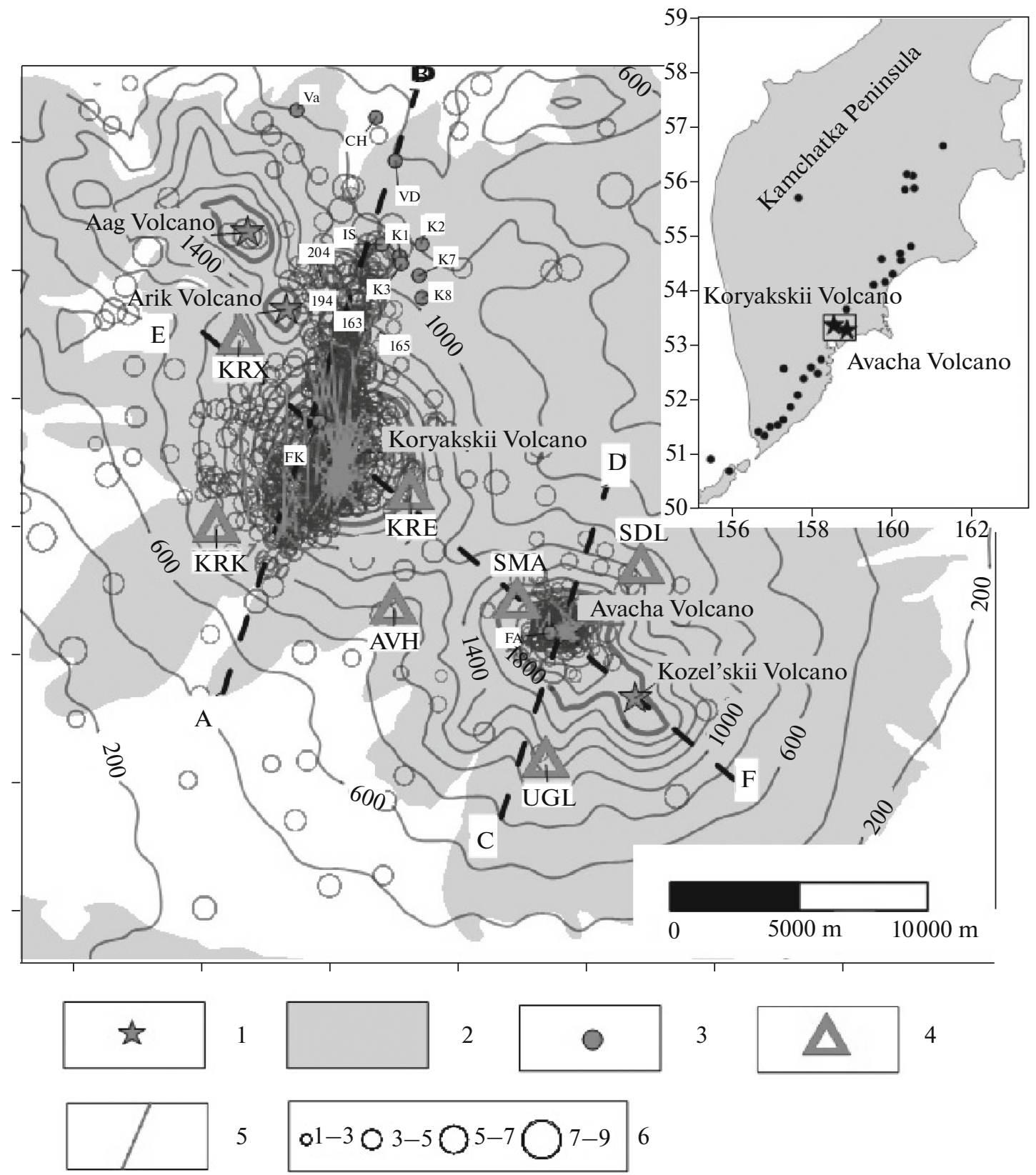

Fig. 1. The distribution of earthquakes (data by the KB GS RAS) and the projections of dike emplacements for the period 20002016 as interpreted from local seismicity data within the Koryakskii-Avacha Volcanic Cluster. The dike projections in the area of the Izotovskii Spring and Koryakskii Narzany are marked with numerals 163, 165, 194, and 204 (see Table 1).

(1) The summits of Avacha, Koryakskii, Kozel'skii, Arik, and Aag volcanoes; (2) ejecta of the volcanoes mentioned above; (3) thermal occurrences: FA fumaroles on Avacha Volcano, FK fumaroles on Koryakskii Volcano; thermal mineral springs: K1, K2, K3, K7; K8 stands for Koryakskii Narzany, IS Izotovskii, VD Vodopadnyi, CH Chistinskii, Va Vakinskii; (4) KB GS RAS seismic stations; (5) dike projections (traces of plane-oriented earthquake cluster areas at abs. altitudes of $-3000 \mathrm{~m}$ abs. beneath Koryakskii Volcano and at $+1500 \mathrm{~m}$ abs. beneath Avacha Volcano; (6) epicenters of 2000-2016 earthquakes (KB GS RAS data) are shown as circles whose diameters are proportional to their energy classes Ks between 1.1 and $8.5, \mathrm{M}=0.5 \mathrm{Ks}-0.75)$. AB, CD, EF are lines of cross-sections in Figs. 2-4. The isolines show the topographic surface, the ticks along axes are at intervals of $5 \mathrm{~km}$. The cluster areas were found using the Frac-Digger program as convex polygons that contain the projections of all hypocenters in a cluster onto the plane $z=a x+b y+c$ (see equation (1) in (Kiryukhin et al., 2016)). 


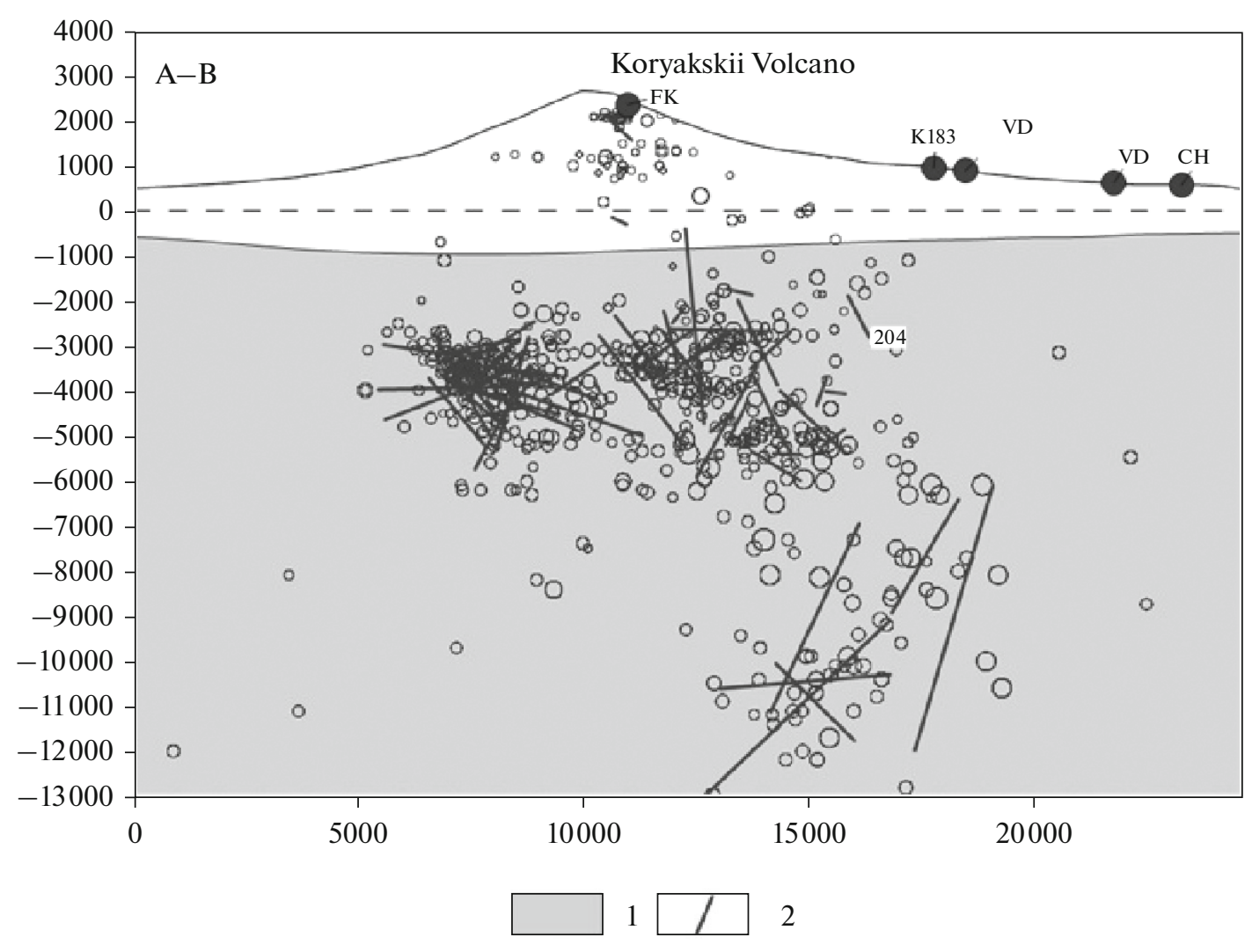

Fig. 2. The distribution of earthquakes as reported by the KB GS RAS and the emplacements of dikes and sills as inferred from local seismicity data and projected onto the plane of the vertical cross-section AB (see Fig. 1), the numeral 204 marking the projection of dike 204 in the area of the Izotovskii Spring and Koryakskii Narzany.

(1) Pre-Cretaceous basement, (2) projections of dike and sill emplacements in the plane of cross-section AB. The rest of the notation is that employed for Fig. 1. Ticks on the axes are at intervals of $1000 \mathrm{~m}$.

$$
A=\left(\begin{array}{ccc}
\cos (\beta) \cdot \cos (\alpha) & -\cos (\beta) \cdot \cos (\alpha) & -\sin (\beta) \\
\sin (\alpha) & \cos (\alpha) & 0 \\
\sin (\beta) \cdot \cos (\alpha) & -\sin (\beta) \cdot \cos (\alpha) & \cos (\beta)
\end{array}\right) .
$$

The tress tensor is accordingly transformed to the fissure coordinates:

$$
S_{\mathrm{f}}=A S_{\mathrm{g}} A^{\mathrm{T}},
$$

where $A^{\mathrm{T}}$ is the transpose of the transformation matrix.

\subsection{The CFRAC Simulation of Magma Injection} into an Inclined Fissure (Where a Dike is Being Formed)

2.2.1. A brief description of the CFRAC program for simulation of geomechanical processes during the injection of magma into sets of fissures. The CFRAC program (McClure, 2012, 2014; McClure and Horne, 2013) deals with sets of equations in hydrodynamics, geomechanics, and in the generation of microearthquakes for discrete $3 \mathrm{D}$ sets of fissures as fluids are injected into them from drilled wells. Elements of the fissures may be displaced or be opened, with the stress (the stress field) due to the deformation being found by finite elements. The program assumes the rock- matrix permeability to be zero, i.e., all fluid flows are specified in the fissures. The respective boundary conditions are applied to these displaced and opening elements of fissures, with no interpenetration of fissures or deformation being assumed against the direction of shear stresses.

2.2.2. The conceptual model and the raw data for CFRAC simulation. Consider the generation of a dike in a fissure (whose angle of dip is $60^{\circ}$ and whose dimensions are $2 \mathrm{~km} \times 2 \mathrm{~km}$ ) due to the injection of magma at depth $z_{0}=6000 \mathrm{~m}$ (or $-3000 \mathrm{~m}$ abs.) beneath Koryakskii Volcano (Fig. 7). We will use the CFRAC program to simulate magma injection (McClure and Horne, 2013). The model deals with the emplacement of a dike from a cylindrical conduit beneath a central-type volcano; Koryakskii and Avacha are of this type (according to the estimate of S.A. Fedotov (1982) such conduits have radii in the range $50-100 \mathrm{~m}$ ).

Our simulation involves the following specifications: the injection of magma into the fissure occurs during 24 hours, the magma discharge is $20000 \mathrm{~kg} / \mathrm{s}$, and the maximum pressure of injection is $200 \mathrm{MPa}$. The magma properties are specified as follows: density 


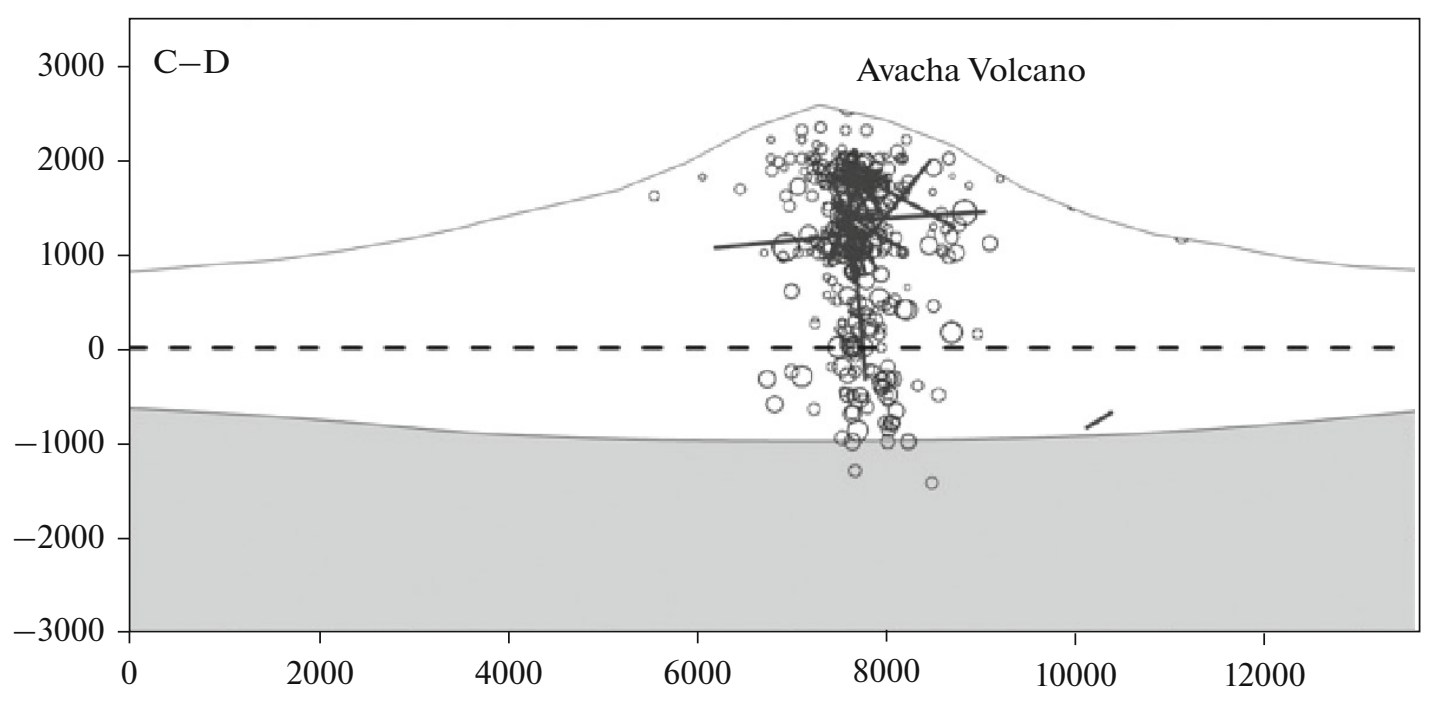

Fig. 3. The distribution of earthquakes as reported by the KB GS RAS and the emplacements of dikes and sills as interpreted from local seismicity data and projected onto the plane of the vertical cross-section CD (see Fig. 1).

The notation is that employed for Figs. 1 and 2. Ticks on the axes are at intervals of $1000 \mathrm{~m}$.

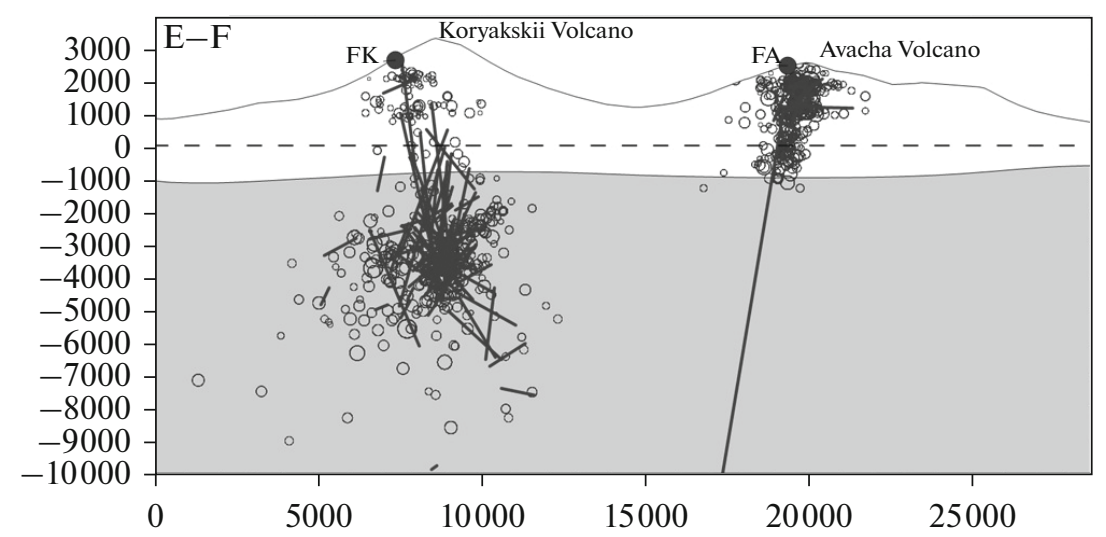

Fig. 4. The distribution of earthquakes as reported by the KB GS RAS and the emplacements of dikes and sills as interpreted from local seismicity data and projected onto the plane of the vertical cross-section EF (Fig. 1).

The notation is that employed for Figs. 1 and 2. Ticks on axes are at intervals of $1000 \mathrm{~m}$.

$2800 \mathrm{~kg} / \mathrm{m}^{3}$ and viscosity $200 \mathrm{~Pa} \cdot \mathrm{s}$. The initial pressure of the magma is $45 \mathrm{MPa}$.

The transformation of the effective stress tensor to the coordinates related to the fissure plane that is centered at a depth of $6000 \mathrm{~m}(-3000 \mathrm{~m}$ abs. $)$, dips west at an angle of $60^{\circ}$, and strikes at $0^{\circ}(X$ is along the dip direction, $Y$ is along the strike, and $Z$ points upward perpendicularly to the fissure plane) leads to the following matrix:

$$
S_{\mathrm{f}}=\left(\begin{array}{ccc}
70.5 & 0 & -40.7 \\
0 & 47.0 & 0 \\
-40.7 & 0 & 23.5
\end{array}\right) .
$$

The stress in the new coordinates related to the fissure plane is thus determined in terms of the C-Frac program as follows: sxx_bc $=70.5 \mathrm{MPa}, \mathrm{sxx} \_\mathrm{z}$ _trend $=$ $18.0 \mathrm{MPa} / \mathrm{km}$, syy_bc $=47 \mathrm{MPa}$, syy_z $\bar{z}$ trend $=$ $14.3 \mathrm{MPa} / \mathrm{km}$, sxy_bc $=-40.7 \mathrm{MPa}$, sxy_z_trend $=$ $0.0 \mathrm{MPa} / \mathrm{km}, \mathrm{szz} \overline{\mathrm{b}} \mathrm{c}=23.5 \mathrm{MPa}$, and szz_z_trend $=$ $10.6 \mathrm{MPa} / \mathrm{km}$. In addition, we also specify the following quantities as being required for the simulation: $G=$ $15000 \mathrm{MPa}$ (the shear modulus), $v=0.25$ (Poisson's ratio), $E_{0}=0.0005$ (the reference opening of the fissure in meters), $e_{0}=0.00005$ (the hydraulic reference opening of the fissure in meters), and $E_{0}=e_{0}$ in the CFRAC program.

2.2.3. The results of CFRAC simulation of magma injection. Figures 8 and 9 illustrate the results of CFRAC simulation (setting_file_7778) after 24 hours since magma began to be injected into the fissure: the distribution of fluid pressure and normal stress in the 


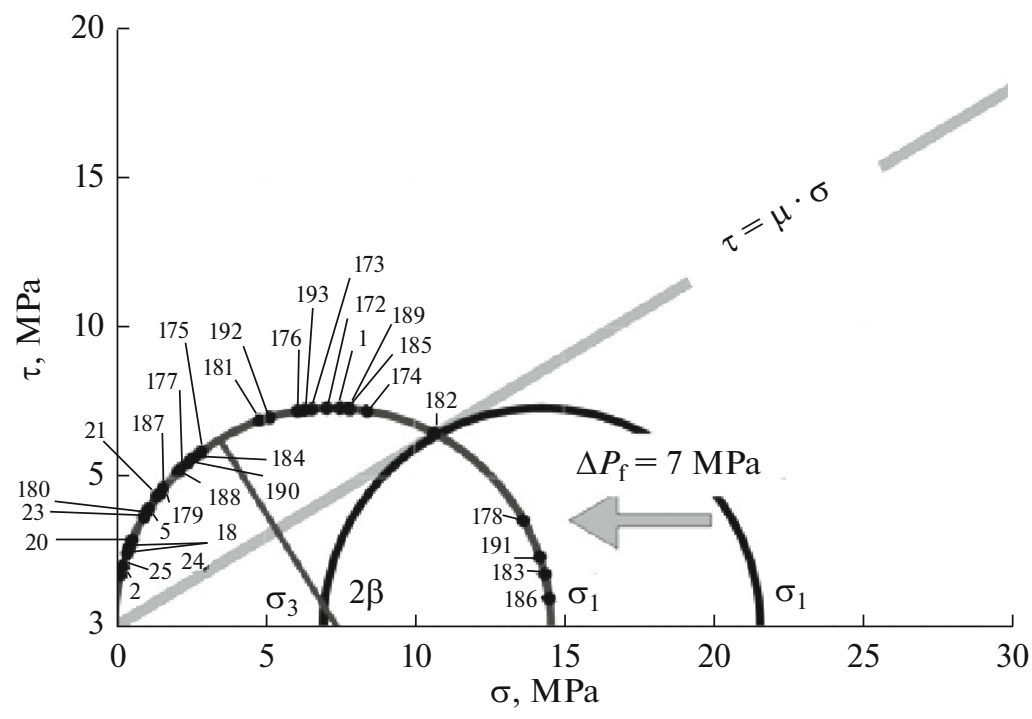

Fig. 5. Mohr diagrams, which show the variation in stress due to magma injection in the cone of Avacha Volcano at a depth of $1000 \mathrm{~m}(\approx 1500 \mathrm{~m}$ abs. $)$.

The circle on the right covers the range of normal and shear stresses before the injection, the circle on the left is for the time after the injection; dots with numerals correspond to dikes and sills (plane-oriented earthquake clusters).

A dot on a circle is positioned by measuring the angle $2 \beta$ from the horizontal axis with the apex at the center where $\beta$ is the dip angle of the plane-oriented cluster.

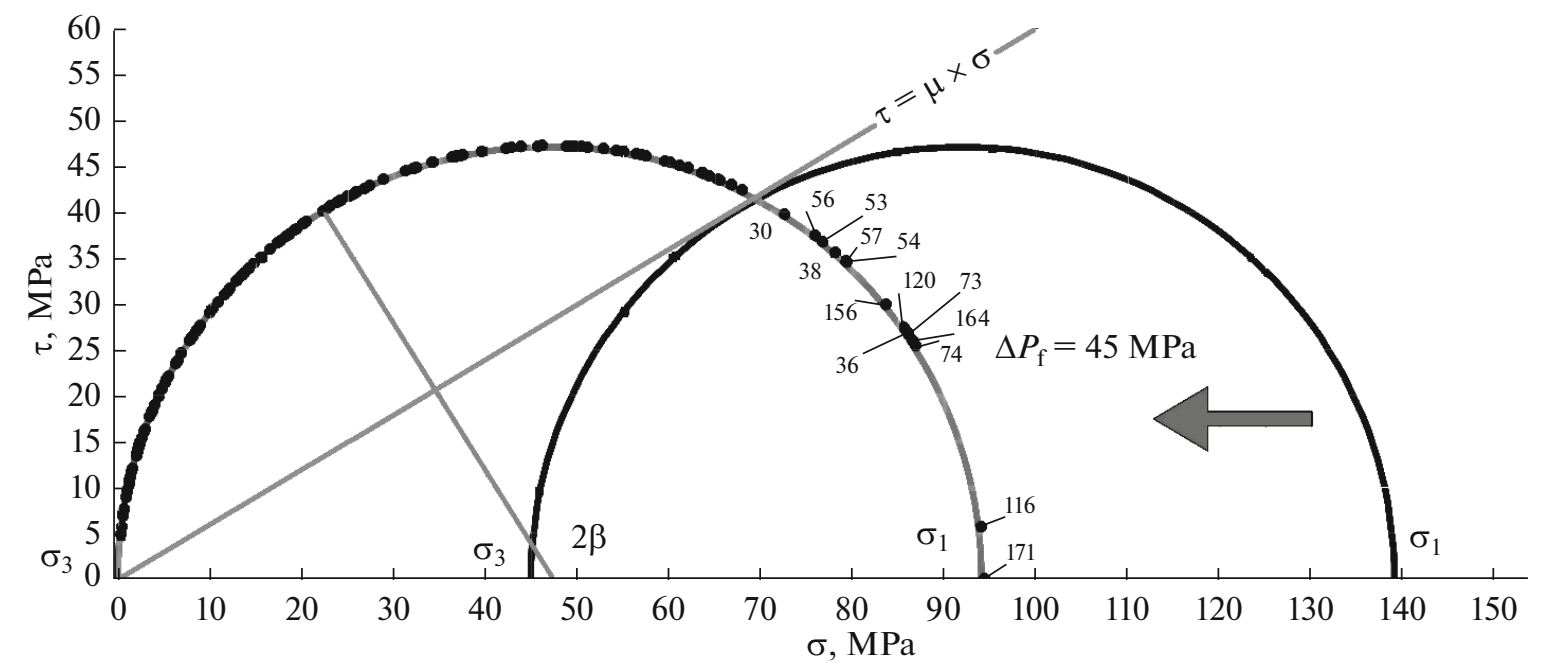

Fig. 6. Mohr diagrams, which show the stress variation due to magma injection at the basement of Koryakskii Volcano at a depth of $6000 \mathrm{~m}(\approx-3000 \mathrm{~m}$ abs. $)$.

The circle on the right covers the range of normal and shear stresses before the injection, the circle on the left is for the time after injection, dots with numerals correspond to gently dipping dikes and sills (plane-oriented earthquake clusters).

A dot is positioned on a circle by measuring the angle $2 \beta$ with the apex at the center from the horizontal axis where $\beta$ is the dip angle of the plane-oriented cluster.

fissure (see Fig. 8), the distribution of fissure opening, the direction of shear (in the "hangingwall" block of the fissure relative to the "footwall" block), and the distribution of the rate of relative shear $(\mathrm{m} / \mathrm{s})$ in fissure walls (see Fig. 9).

The inner part of the fissure (whose radius is approximately $500 \mathrm{~m}$ ) has a fluid pressure of 60-90 MPa (the excess pressure is $15-45 \mathrm{MPa}$ ) and an opening varying from $0.02 \mathrm{~m}$ at the periphery to $0.3 \mathrm{~m}$ in the middle; the normal stresses vanish in this region. The volume of the dike due to magma injection is in agreement with the discharge of magma: $60800 \mathrm{~m}^{3}$. Magma injection makes the upper plane of the fissure slide relative to its lower plane (shear-type deformation) and 


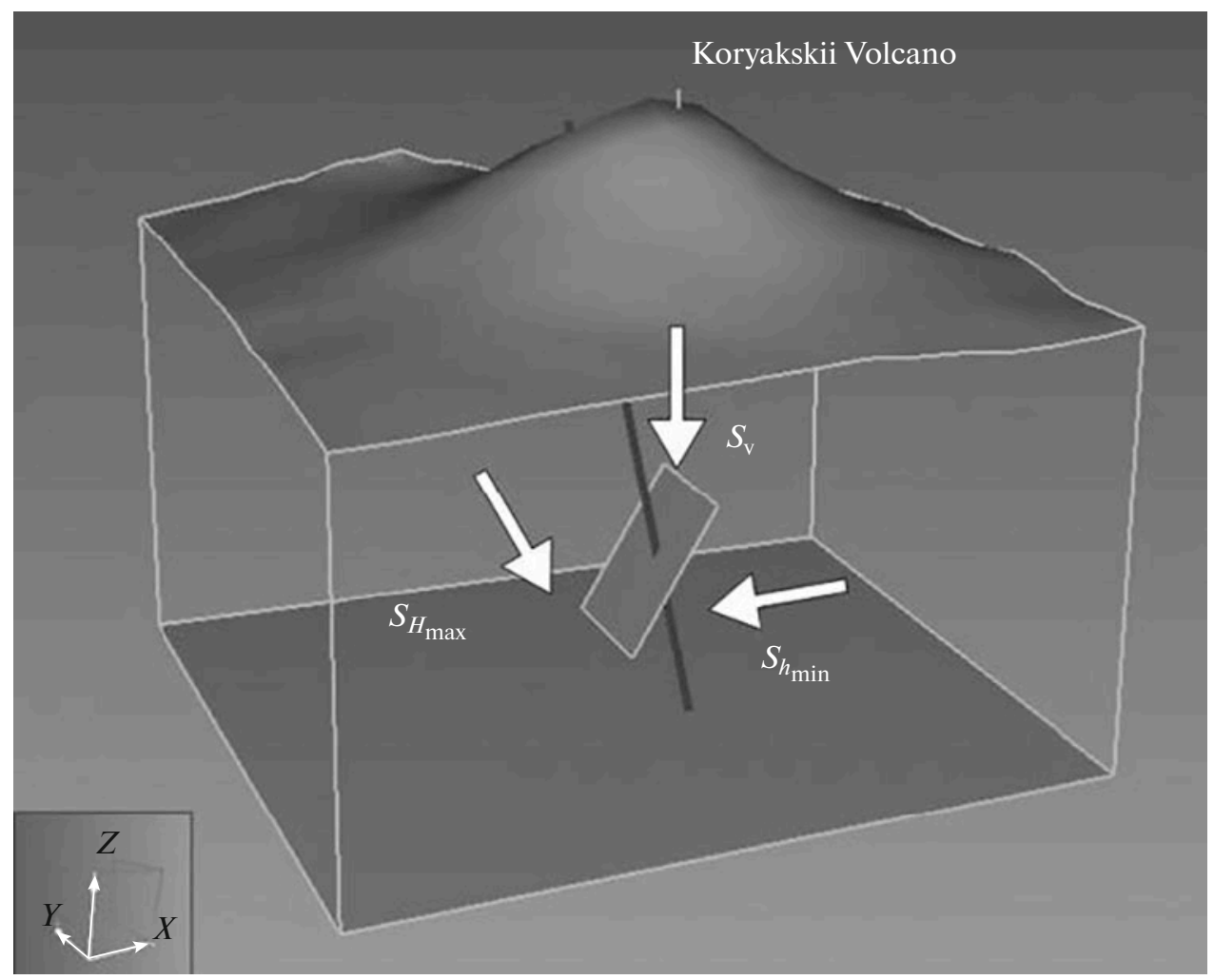

Fig. 7. A conceptual model to explain the generation of a dike due to magma injection in a setting of east-west tension. $S_{\mathrm{v}}, S_{H_{\max }}$, and $S_{H_{\min }}$ are the directions of vertical, maximum horizontal, and minimum horizontal stresses in the geographic coordinates $X Y Z$ ( $X$ points north, $Y$ points east, and $Z$ is the absolute altitude).

this can be seen fairly well in a cumulative strike-slip movement in the fissure plane (from $1 \mathrm{~m}$ at the periphery to $3 \mathrm{~m}$ in the upper part). The rate of shear deformation in the upper part of the fissure reaches $7.8 \times 10^{-6} \mathrm{~m} / \mathrm{s}$ (at 24 hours after the magma injection began). The maximum rates of shear movement in the fissure walls are reached at the initial time of the fissure opening, e.g., in 570 seconds they reach $2.9 \times 10^{-4} \mathrm{~m} / \mathrm{s}$. Figure 9 shows regions where the fissure walls experience the maximum rates of movement; these regions are the hypocenter zones of plane-oriented earthquake clusters.

The CFRAC program assumes the threshold value of shear rate at which it initiates an earthquake during the injection of water to be $1 \times 10^{-3} \mathrm{~m} / \mathrm{s}$; at this time the associated seismicity records the element of the model where the above requirement is fulfilled and an earthquake rupture starts. The record of the associated microearthquake is over when the maximum shear rate has decreased to reach the threshold value. The parameters of the earthquakes thus recorded (time, hypocenter coordinates, seismic moment and magnitude, the variation of the seismic rupture front propagation) are all saved in the resulting files. The experience in using the CFRAC program (J. Norbeck, pers. com) shows that the microearthquakes as located using the above procedure last no longer than $1 \mathrm{sec}-$ ond, while the time intervals between individual events may be a few days to a few months.

The seismic moment $M_{0}$ is found in application to a shear fissure as follows: $M_{0}=G \int \operatorname{slip} d A$, where $G$ is the shear modulus, slip is the amount of the respective movement, and $A$ is the shear area, with the integral being calculated by adding the shear movements during the earthquake rupture times for the surface areas of the respective elements of the fissure. The next step is to find the magnitude: $M_{\mathrm{w}}=\log \left(M_{0}\right) / 1.5-$ 6.06 (where $M_{0}$ is in $\mathrm{N} \mathrm{m}$ ).

For regions with higher rates of shear strain as shown in Fig. 9, the seismic moment when calculated from the above relationship is $M_{0}=5.7 \times 10^{15}-6.8 \times$ $10^{15} \mathrm{~N} \cdot \mathrm{m}$, which corresponds to earthquake magnitudes in the range of 4.4-4.5 ( $\mathrm{Ks}=7.4-7.6)$.

2.2.3. The results of CFRAC simulation: the injection of a low-viscosity magma. Our simulation of the injection of a magma with a lower viscosity (2-20 Pa s) shows an asymmetrical upward propagation of the magma-induced fissure and increased rates of shear at the fissure walls reaching $2 \times 10^{-3} \mathrm{~m} / \mathrm{s}$, i.e., the 


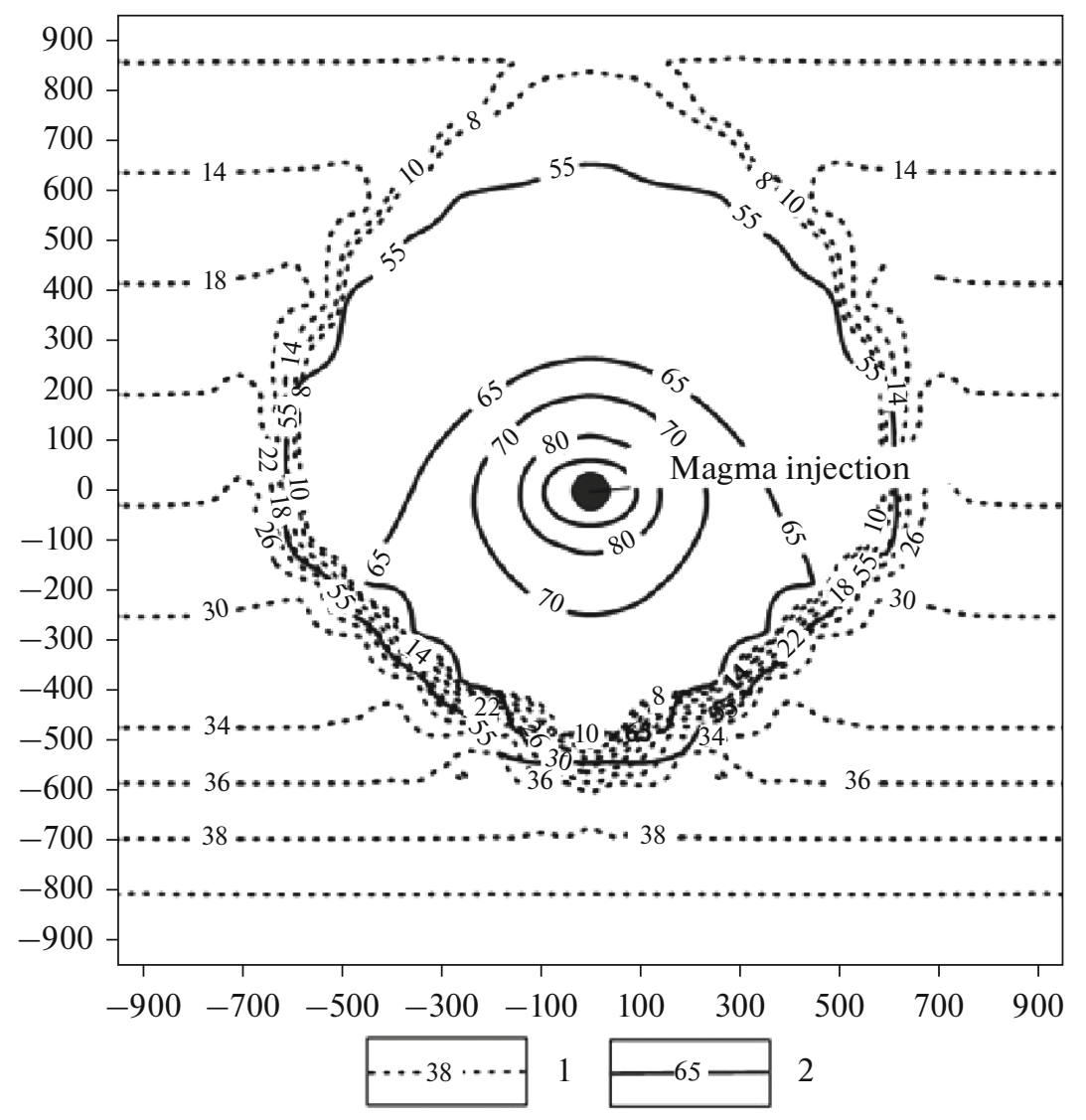

Fig. 8. The results of hydromechanical simulation of magma injection beneath Koryakskii Volcano (the injection depth is $6 \mathrm{~km}$ ) using the CFRAC program (McClure, 2014). The distribution of magma pressure and effective normal stress in the fissure plane (the position of the fissure is shown in Fig. 7) is shown after 24 hours since the magma injection began, the ticks on the axes are in meters.

(1) Isolines of effective normal stress (MPa), (2) isolines of magma pressure (MPa).

emplacement of less viscous basaltic magmas produces better pronounced microseismicity.

\section{THE THERMAL EFFECT OF DIKE EMPLACEMENT: THE IZOTOVSKII SPRING}

The temperature at the Izotovskii Spring (IS in Fig. 1), which can be as hot as $50^{\circ} \mathrm{C}$ and which is $7 \mathrm{~km}$ from Koryakskii Volcano, was recorded automatically using a HOBO U12 logger with a sampling rate of $15 \mathrm{~min}$. Four plane-oriented earthquake clusters have been recorded in the area of the Izotovskii Spring and Koryakskii Narzany during 2000-2016. These clusters (nos. 163, 166, 194, and 204) are interpreted as dike emplacements (see Table 2, Figs. 1 and 2).

Figure 10 clearly shows a postmagmatic temperature increase of $6-12^{\circ} \mathrm{C}$ during the winter period between October 2011 and June 2012 after a hypothetical dike emplacement on August 2, 2011: an increase in maximum monthly temperature $T_{\max }$ was recorded by $6-12^{\circ} \mathrm{C}$ relative to the average seasonal maximum monthly temperature $T_{\mathrm{av}}$. This means that the temperature wave from the cooling dike arrived at the spring 2 months after the emplacement, with the anomalous temperature regime persisting at the spring for 10 months afterwards. A temperature increase at the Izotovskii Spring by as much as $10^{\circ} \mathrm{C}$ that was synchronized with the dike emplacement of February 28, 2016 was also recorded in 2015-2016.

\section{RESULTS AND DISCUSSION}

The resumption of activity on Koryakskii Volcano in 2008-2009 was examined in a series of papers devoted to the analysis of its geological causes and accompanying hydrogeological changes. Seliverstov (2009) explains the resumption of activity on Koryakskii by the geodynamic setting, viz., a north-south trending tension zone. In the case under consideration, the east-west extension reduces the minimum horizontal stress Shmin and can theoretically speaking (if Shmin is lower by $45 \mathrm{MPa}$ at a depth of $6 \mathrm{~km}$ ) lead to the origination of normal faults in compliance with the failure conditions shown in the Mohr diagram (see Fig. 6). Gordeev et al. (2009) proposed the idea that the hydrothermal reservoir beneath Koryakskii Vol- 


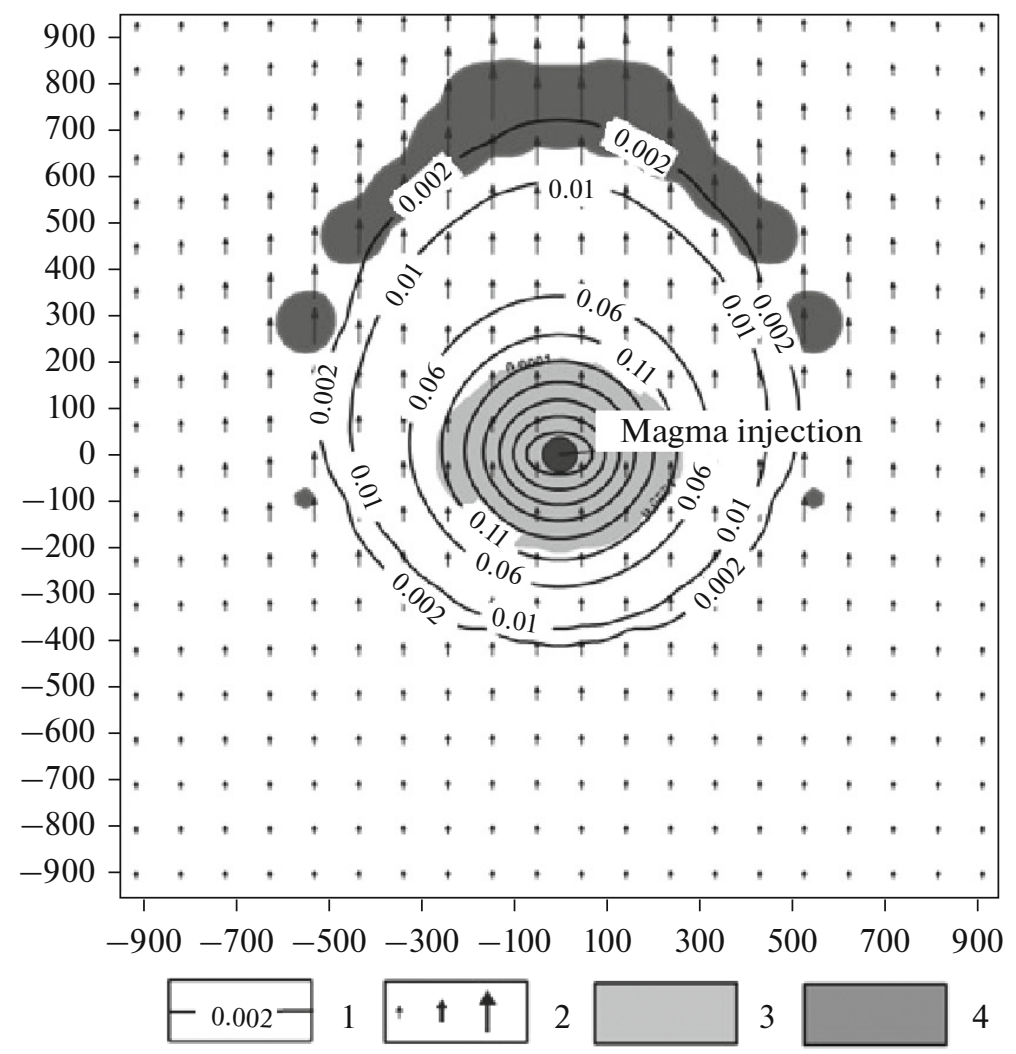

Fig. 9. Results of hydromechanical simulation of magma injection beneath Koryakskii Volcano at a depth of $6 \mathrm{~km}$ using the CFRAC program (McClure, 2014). The distribution of fissure opening (the fissure position is shown in Fig. 7), the directions of shear strains after 24 hours since the magma injection began, and the hypocenter zones of plane-oriented earthquake clusters. The ticks on the axes are in meters.

(1) Isolines of fissure opening $(\mathrm{m})$; (2) vectors of shear direction (for the "footwall" block of the fissure relative to the "hangingwall" block, the vector lengths are proportional to the magnitude the shear). The arrow lengths shown in the legend correspond to shear deformation equal to $1 \mathrm{~m}, 2 \mathrm{~m}$, and $3 \mathrm{~m} ;(3,4)$ zones of higher rates of relative fissure wall displacement: $(3)$ rates above $10^{-4} \mathrm{~m} / \mathrm{s}$ as observed $570 \mathrm{~s}$ after the magma injection, (4) rates above $3 \times 10^{-6} \mathrm{~m} / \mathrm{s}$ as observed 24 hours after the magma injection.

Aug. 2, 2011

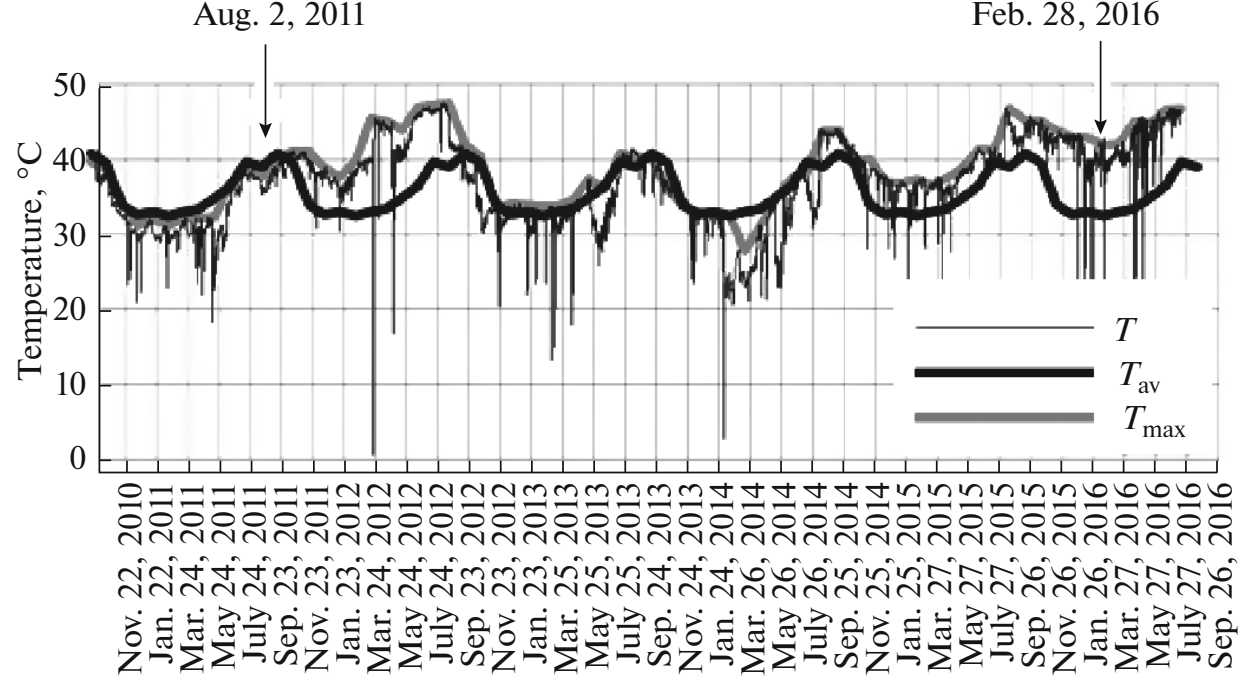

Fig. 10. The variation in temperature for the Izotovskii Spring and dike injections as identified from interpretation of local seismicity data (no. 194 on August 2, 2011 and no. 204 on February 28, 2016, see Table 1) in the immediate vicinity of the spring discharge in the northern sector of Koryakskii Volcano.

$T$ denotes recorded data, $T_{\mathrm{av}}$ is the average seasonal maximum monthly temperature, and $T_{\max }$ is the maximum monthly temperature. 
cano showed increased seismicity due to magma intrusions. This mechanism can obviously occur by resumed activity of normal faulting, as shown in the Mohr diagram (see Fig. 6), but in that case the excess pressure of magma must be as high as $45 \mathrm{MPa}$ at a depth of $6 \mathrm{~km}(-3 \mathrm{~km}$ abs.) and magma must have been active to produce hydraulic fracture (this case is considered in the present paper).

Observations of the water level at well E1 drilled $15 \mathrm{~km}$ from Koryakskii Volcano showed an increase of $1.2 \mathrm{~m}$ during the 2008-2009 activity (Kopylova and Boldina, 2012). These authors explain the effect as being due to compression of water-bearing rocks and increasing pore pressure (by 0.12 bars). In our opinion, this increase could also be caused by intensified gas generation of methane in the Koryakskii-Avacha volcanogenic basin due to magma intrusions. For this reason water-level observations tend to indicate injections of fluids in the volcanogenic basin during 20082009 rather than its extension resulting from global tectonic processes.

Besides tectonic forces (see above), the only alternative agent to cause fissures of hydraulic fracture, apart from magma, could be water. However, no artesian wells with abnormally high pressure have been detected within the Koryakskii-Avacha volcanogenic basin, hence the generation of hydraulic fracture fissures by water (according to the Mohr diagram) with the excess pressures indicated in Figs. 5 and $6(45 \mathrm{MPa} /-3000 \mathrm{~m}$ abs and $7 \mathrm{MPa} /+1500 \mathrm{~m}$ abs) is impossible.

The postmagmatic heating of the Izotovskii Spring (the winters of 2012 and of 2016, see Fig. 10), which is $7 \mathrm{~km}$ north of Koryakskii Volcano, also provides evidence in favor of a seismicity increase in the hydrothermal reservoir due to magma intrusions (Gordeev et al., 2009).

An analysis of the mechanisms of volcanic earthquakes for 2008-2009 (Lemzikov and Lemzikov, 2015) based on the first P motions indicates a planeoriented character of the earthquake-associated faults, their nearly north-south orientation, and location at different depths $(1.8-4.2 \mathrm{~km})$ south of the Koryakskii summit and (at depths of 4.2-12.7 km) north of it; these are all in good agreement with the characteristics of plane-oriented earthquake clusters shown in Figs. 1 and 2, pointing to a (probably hydraulic) connection to the central conduit of the volcano.

\section{CONCLUSIONS}

An analysis of local seismicity in the AvachaKoryakskii Volcanic Cluster area for the 2000-2016 period revealed a sequence of plane-oriented earthquake clusters, which are interpreted here as resulting from the emplacement of dikes and sills. The highest magmatic activity was synchronized with the 20082009 steam-gas eruption of Koryakskii Volcano (the prevailing depths of emplacements were between -5 and $-2 \mathrm{~km}$ abs.), with the injection of magma subsequently moving into the cone of Avacha Volcano in
2010-2016 (the prevailing depths of emplacements were between 1 and $2 \mathrm{~km}$ abs.). The geometry of the magma bodies reflects the geomechanical tension conditions at the basement of Koryakskii Volcano dominated by vertical stresses $S_{\mathrm{v}}$, with the maximum horizontal stress $S_{H_{\max }}$ pointing north.

The hydrogeomechanical simulation of magma injection in a fissure with properties that are characteristic for the basement of Koryakskii Volcano (dip angle is $60^{\circ}$, the dimensions are $2 \times 2 \mathrm{~km}^{2}$, and the depth $4 \mathrm{~km}$ abs.) using the CFRAC program (McCluer, 2014) showed that when the discharge of magma is $20000 \mathrm{~kg} / \mathrm{s}$ during 24 hours, the fissure opening increases to reach $0.3 \mathrm{~m}$, the magma injection is accompanied by shear deformation occurring at a rate reaching $2 \times 10^{-3} \mathrm{~m} / \mathrm{s}$, which coincides with the conditions of local seismic events with $\mathrm{Mw}$ reaching 4.5. To sum up, the use of plane-oriented earthquake clusters for identifying magma emplacements has been justified by the results of our hydromechanical simulation.

The seismicity increase on August 2, 2011 in the area of the Izotovskii hot spring $(7 \mathrm{~km}$ from the summit of Koryakskii Volcano), which is interpreted here as the emplacement of a dike, is corroborated by an increase in the temperature of this spring by $10-12^{\circ} \mathrm{C}$ during the period from October 2011 to July 2012. The equipment with loggers (self-operating devices for temperature recording) will provide additional information on the thermal influence of the system of magmatic conduits beneath Koryakskii Volcano on the adjoining hydrothermal system in order to record the temperature regime of Koryakskii Narzany (nos. 1, 2, and 8).

The quality and completeness of the available raw data and the uncertainty of hypocenter location, which determine the possibilities of this method for investigating the mechanism of activity of the Koryakskii-Avacha Volcanic Cluster, are controlled by the catalogs of the KB GS RAS, with the catalogs and hypocenter coordinates being updated. For this reason some of the above results can be updated after obtaining more complete and accurate data on earthquake hypocenter coordinates. Independent estimates of the rates of emplacement and thicknesses of dikes can be derived by thermal calculations. Further research must aim at the acquisition of high-precision geodetic data, viz., satellite-based radar surveys (InSAR) and denser networks of GPS/GLONASS stations. Such new information will supplement and refine our knowledge of the properties of the magmatic plumbing system beneath the major Koryakskii-Avacha Volcanic Cluster and of the mechanism of volcanic activity.

\section{ACKNOWLEDGMENTS}

We express our sincere thanks to T.V. Rychkova, V.K. Grigor'ev, P.O. Voronin, A.Yu. Polyakov, A.V. Mushinskii, T.G. Churikova, I.K. Dubrovskaya, 
D.V. Mel'nikov, Ya.D. Murav'ev, I.F. Delemen', V.K. Lemzikov, S.L. Senyukov, V.V. Ivanov, S.N. Rychagov, G.N. Kopylova, and M.V. Lemzikov for help organizing the field work and the processing and discussion of the results. We are also grateful to $\mathrm{M}$. McClure and R. Horne for the license of the CFRAC program.

This work was supported by the Russian Science Foundation for the project 16-17-10008.

\section{REFERENCES}

Dumont, S., Klinger, Y., Socquet, A., et al., Magma influence on propagation of normal faults: Evidence from cumulative slip profiles along Dabbahu-MandaHararo rift segment (Afar, Ethiopia), J. Structural Geology, 2017, no. 95 , pp. 48-59.

Fedotov, S.A., On the ascent of basic magmas in the Earth's crust and on the mechanism of basaltic fissure eruptions, Izv. AN SSSR, 1976, no. 10, pp. 5-23.

Fedotov, S.A., The calculation of feeding conduits and magma chambers of volcanoes with stable dimensions and temperatures, Vulkanol. Seismol., 1982, no. 3, pp. 3-17.

Fedotov, S.A., On the emplacement of dikes and on the mechanism of fissure eruptions, Vulkanol. Seismol., 1982, no. 5, pp. 79-95.

Fedotov, S.A., On the eruption in the Akademii Nauk Caldera and on Karymskii Volcano, Kamchatka in 1996, the study and mechanism of these, Vulkanol. Seismol., 1997 , no. 5, pp. 3-37.

Fedotov, S.A., Magmaticheskie pitayushchie systemy i mekhanizm izverzhenii vulkanov (Plumbing Systems and the Mechanism of Volcanic Eruptions), Moscow: Nauka, 2006.

Fedotov, S.A., Sugrobov, V.M., Utkin, I.S., and Utkina, L.I., On the possibility of using heat stored in the magma chamber of the Avachinsky Volcano and the surrounding rock for heat and power supply, J. Volcanol. Seismol., 2007, vol. 1, no. 1, pp. 28-41.

Gordeev, E.I., Droznin, V.A., Dubrovskaya, I.K., et al., Koryakskii Volcano: The present state and activation of 2008-2009, in Materialy IV Vseross. Simpoziuma po vulkanologii $i$ paleovulkanologii. Vulkanizm i geodinamika (Proc. IV All-Russia symposium on Volcanology and Paleovolcanology. Volcanism and Geodynamics), vol. 2, Petropavlovsk-Kamchatskii: IViS DVO RAN, 2009, pp. 588-590.

Gordeev, E.I. and Droznin, V.A., The temperature of the explosive plume due to the 2009 eruption of Koryakskii Volcano, Dokl. Akad. Nauk, 2010, vol. 430, no. 3, pp. 349-351.

Gudmundsson, A., Magma chambers: Formation, local stresses, excess pressures, and compartments, J. Volcanol. Geotherm. Res., 2015, vol. 237-238, pp. 19-41.

Kiryukhin, A.V., Manukhin, Yu.F., Fedotov, S.A., et al., Geological fluids in the Avacha-Koryakskii volcanogenic basin, Kamchatka, Geoekologiya. Inzhenernaya Geologiya. Gidrogeologiya. Geokriologiya, 2015, no. 5, pp. 400-414.

Kiryukhin, A.V., Fedotov, S.A., and Kiryukhin, P.A., A geomechanical interpretation of the local seismicity related to eruptions and renewed activity on Tolbachik, Koryakskii, and Avacha Volcanoes, Kamchatka, in
2008-2012, J. Volcanol. Seismol., 2016, vol. 10, no. 5, pp. 275-291.

Kopylova, G.N. and Boldina, S.V., On the relationships of water-level variations in the E-1 well, Kamchatka to the 2008-2009 resumption of activity on Koryakskii volcano and to large $(M \geq 5)$ earthquakes J. Volcanol. Seismol., 2012, vol. 6, no. 5, pp. 316-328.

Lemzikov, V.K. and Lemzikov, M.V., A study of the focal mechanisms of small volcanic earthquakes during the precursory period and the occurrence of the 20082009 eruption on Koryakskii Volcano, J. Volcanol. Seismol., 2015, vol. 9, no. 6, pp. 378-386.

Lundgren, P., Kiryukhin, A., Milillo, P., and Samsonov, S., Dike model for the 2012-2013 Tolbachik eruption constrained by satellite radar interferometry observations, J. Volcanol. Geotherm. Res., 2015, vol. 307, pp. 79-88.

McClure, M.W., Modeling and Characterization of Hydraulic Stimulation and Induced Seismicity in Geothermal and Shale Gas Reservoirs, PhD Thesis, Stanford, California: Stanford University, 2012.

McClure, M.W. and Horne, R.N., Discrete Fracture Network Modeling of Hydraulic Stimulation: Coupling Flow and Geomechanics, Springer, 2013. doi 10.1007/978-3319-00383-2

McClure, M., CFRAC Complex Fracturing Research Code User's Guide (version 20), December 2014. 88 p.

Nicolas, C., Michel, F., Catherine, D., et al., Induced microseismic activity during recent circulation tests at the EGS site of Soultz-Sous-Forest (France), in Proc. Thirty-Sixth Workshop on Geothermal Reservoir Engineering, Stanford, California: Stanford University, January 31 - February 2, 2011. SGP-TR-191.

Polyak, B.G., On the character of the geotemperature field in the area of Avacha Volcano, Dokl. Akad. Nauk SSSR, 1964, vol. 154 , no. 2, pp. 329-332.

Seliverstov, N.I., An activation of Koryakskii Volcano in Kamchatka, Vestnik KRAUNTs. Nauki o Zemle, 2009, no. 1 , Issue. 13 , pp. 7-9.

Senyukov, S.L. and Nuzhdina, I.N., The 1966-2009 seismicity of Koryakskii Volcano, in Trudy Vtoroi regional'noi nauchno-tekhnicheskoi konferentsii: Problemy kompleksnogo geofizicheskogo monitoringa Dal'nego Vostoka Rossii (Proc. Second regional conf. "Problems in Multidisciplinary Geophysical Monitoring of the Russian Far East"), Petropavlovsk-Kamchatskii: KF GS RAN, 2010, pp. 91-95.

Shteinberg, G.S. and Zubina, M.I., On the depth to the magma chamber beneath Avacha Volcano, Dokl. Akad. Nauk SSSR, 1963, vol. 152, no. 4, pp. 968.

Sigmundsson, F., Hooper, A., Hreinsdorttir, S., et al., Segmented lateral dyke growth in a rifting event at Barrparbunga volcanic system, Iceland, Nature, 2015, vol. 517, pp. 191-194. doi 10.1038/nature 14111

Zemletryaseniya Rossii v 2013 godu (Earthquakes in Russia during 2013), Obninsk: GS RAN, 2015. 224 pp. illustr. + 1 electr. Opt. disk (CD-ROM).

Zemletryaseniya Rossii v 2014 godu (Earthquakes in Russia during 2013), Obninsk: GS RAN, 2016. 204 pp. illustr. + 1 electr. Opt. disk (CD-ROM).

Zoback, M.D., Reservoir Geomechanics, Cambridge University Press, 2010.

Translated by A. Petrosyan 